\title{
Activation of Cognitive Activities of 5-6 Grade Students on Lessons of Labor Learning
}

Andriy TSINA, V.G. Korolenko National Pedagogical University, Poltava, Ukraine, andriy_tsina@rambler.ru ORCID: https://orcid.org/0000-0002-8353-9153

Valentina TSINA, V.G. Korolenko National PEDAGogical UNIVERSity, PoltaVA, UKRAINE, AJUT1959@GMaIL.COM ORCID: HTTPS://ORCID.ORG/0000-0002-3512-1641

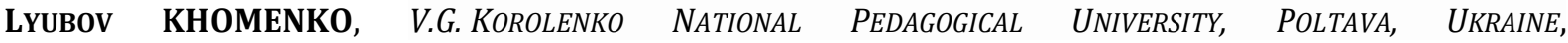
LJUDV.DZJUBA@GMAIL.COM ORCID: HTTPS://ORCID.ORG/0000-0001-6806-2783

NYKOLAY BLYZNIUK, V.G. KOROLENKO NATIONAL PEDAGOGICAL UNIVERSITY, POLTAVA, UKRAINE, BLYZNIYK@GMAIL.COM ORCID: HTTPS://ORCID.ORG/0000-0002-8339-4118

Julia SRIBNA, V.G. Korolenko National Pedagogical University, Poltava, Ukraine, pnpu22@gmail.com ORCID: https://orcid.org/0000-0003-3846-3871

\begin{abstract}
The article is devoted to the problem of activation of the cognitive activity of 5-6 grade students in the lessons of labor training. The purpose of the study was to substantiate the pedagogical conditions and develop methods for enhancing the cognitive activity of students in grades 5-6 in the process of studying the technology of household activities and self-service, as well as develop experimental testing of the methods' effectiveness. The experimental method of revealing the effectiveness of the introduction of pedagogical conditions for the activation of cognitive activity of secondary school students was used. The results allowed to clarify the essence of the concept of activation of cognitive activity, and to study the application of certain pedagogical conditions by teachers of labor training and students' attitudes to learning the basics of everyday life and self-service. The importance of the availability of educational material on household activities and self-service for its assimilation by students, the degree of importance of pedagogical conditions for activating cognitive activity for teachers of labor education, and the dynamics of changes in levels of cognitive activity of students during the study of technology of household activities and self-service were determined. The basic model of activation of the students' cognitive activity has been proposed.
\end{abstract}

Keywords: domestic activity, self-service, labor training, cognitive activity, activation, pedagogical conditions.

Received: $16.12 .2020 \quad$ Accepted: 10.01.2021 $\quad$ Published: 09.02.2021

\section{INTRODUCTION \\ Background}

The importance and complexity of the tasks facing the secondary school today require increasing the level of activity of students in the educational process, in particular in the lessons of work training. From a psychological and pedagogical point of view, the solution to this problem is connected with the provision of conditions that contribute to the activation of cognitive activity of primary school students in the lessons of work training.

The active cognitive activity of students is an important factor in the successful interaction between teacher and student. It is in such interaction that the main meaning of organizing the educational process in a comprehensive school is laid down, since becoming a learner as a subject of activity during learning ensures his active life position not only in the years of study but also in the future independent life.

The purpose of the article is to substantiate the pedagogical conditions and to develop a method of activating cognitive activity of 5-6 grade students in the process of studying technology of domestic activity and self-service in the lessons of labor training and to experimentally test its effectiveness. To achieve this goal, the following tasks are defined: (i) to reveal theoretical bases of activation of cognitive activity of students in the modern secondary school; (ii) to substantiate the pedagogical conditions for activating the cognitive activity of students in labor education; (iii) to develop a method of activation of cognitive activity of students of 5-6 grades in the process of studying technology of domestic activity and self-service; (iiii) experimentally check the effectiveness of the developed methodology. 
The problem of activation of cognitive activity has been and is the subject of research of many domestic and foreign scientists, methodologists and teacher-practitioners: G. Kameneva and T. Bondarenko (2018), W. Plöger et al. (2019), A. Wischgoll et al. (2019), P. Ya. Gal'perin (1992), V. V. Davydov (1996), M. Ya. Ihnatenko (1997), G. S. Kostyuk and L. N. Prokoliyenko (1988), A. N. Leont'yev (1975), O. Ya. Savchenko (1997), O. Ye. Sushentsev (2002), T. I. Shamova (1982), B. D. El'konin (2004), T. Giovazolias et al. (2019) and others. The problem of management of active educational and cognitive activity is covered in the works of S. Rieser et al. (2016), V. I. Lozova and H. V. Trotsko (2002), T. I. Shamova et al. (2002), J. P. Becerra-Romero et al. (2020), A. Hornsby-Gutting (2019) and others.

According to the analysis of psychological and pedagogical literature, there is insufficient research on the activation of cognitive activity of primary school students in the study of particular topics and sections of labor education. These studies are predominantly related to: general didactic foundations of cognitive activity of students in the lessons of work training (Skomorovs'kyy, 1996; Plöger et al., 2019; Haruna et al., 2019); didactic foundations of problems in the lessons of labor training (Rieser et al., 2016; Tkhorzhevs'kyy, 2000; Zammitti et al., 2020); design and technological activity of students in the lessons of labor training (Kameneva \& Bondarenko, 2018; Berbets et al., 2003; Kobernyk, 2010; Yashchuk, 2002).

At the present stage, there is a contradiction between increasing the requirements for the activation of cognitive activity of students in the lessons of work training and the available methodological support. Thus, the urgent task for today is to identify ways to activate cognitive activity of students of 5-6 grades in the lessons of labor training in the process of studying individual topics and sections of the curriculum, in particular, and technologies of everyday activities and self-care.

In order to uncover the theoretical foundations for activating the cognitive activity of students in secondary school, let's examine in more detail the essence of such concepts as activity, cognitive activity, activation of cognitive activity.

In the psychological dictionary written by L. A. Karpenko, the concept of activity is interpreted as "a dynamic system of active interaction of the subject with the outside world, in the course of which the subject actively influences the object, thereby meeting his needs" (Psikhologiya: slovar', 1990, p. 84). In the system of activity are transformative, cognitive, communicative, orientational, executive types.

Cognitive activity is an important component of human activity, which is associated with the acquisition of new knowledge and determines the development of society and man himself. Scientists define cognitive activity as the unity of sensory perception, theoretical thinking and practical activity (Slastenin et al., 2002), noting that it is conscious and directed to the knowledge of the surrounding reality through such mental processes as perception, thinking, memory, attention, language (Vygotskiy, 1991).

Activity is a characteristic of an activity and is an indicator of its level. The term activity comes from the Latin actives, which means active, energetic, initiative and includes: (i) the properties of the body and psyche, depending on external and internal needs; (ii) the personality trait that manifests itself in the active initiative attitude towards the world and ourselves (Bondarchuk, 2001, p. 21).

Cognitive activity is a personality trait that manifests itself in its attitude to cognitive activity and implies a state of readiness, a desire to mobilize their moral and volitional efforts to assimilate the individual's social experience, accumulated by humanity of knowledge and ways of activity, and also manifests itself as cognitive activity (Ihnatenko, 1997; Skomorovs'kyy, 1996).

Student activity management has traditionally been called activation. The concept of activation of students' educational and cognitive activity is interpreted as "... the mobilization by the teacher (with the help of special means) of intellectual, moral, volitional and physical forces of students to achieve the specific goal of learning, education and comprehensive development of students, to strengthen joint educational and cognitive activity and students, encouragement to energetic purposeful exercise, overcoming inertia, passivity, stereotyped forms of teaching and learning" (Ihnatenko, 1997, p. 21).

An analysis of literary sources on the work training of students in the modern school (Kobernyk \& Sydorenko, 2011; Sushentseva \& Sushentsev, 2000; Plöger et al., 2019; Sushentsev, 2002; Yashchuk, 2002; Zammitti, et al., 2020; Haruna et al., 2019) showed that today there are teachers in the arsenal of general education teachers a considerable number of means of activating the cognitive activity of students. The means of activating the cognitive activity of students may be: principles, content, forms of organization, teaching methods, cross-curricular links, clarity, independent work of students, material base of the educational process, personal qualities of the teacher, but the basis for it is the actions of students in the perception of educational material and development solving problematic issues that arise during training (Giovazolias et al., 2019).

Creating certain pedagogical conditions will be an effective way of stimulating the cognitive activity of students. Appeal to pedagogical research (Berbets et al., 2003; Kaloshyn, 2011; Sushentseva \& Sushentsev, 2000; Wischgoll et al., 2019; Mahfudet al., 2020) showed that pedagogical conditions for 
successful activation of cognitive activity of students in the educational and educational process be the following: systematic, purposeful development of motivation of students' educational and work activities; creating a success situation in cognitive activity; differentiation of the learning process; organization of problem training; the use of a computer-based training system.

Systematic, purposeful development of the motivation of students' educational and labor activity, as a pedagogical condition for increasing the activation of cognitive activity of students, involves the creation of a motivational and purpose component of cognitive activity of students, which involves the design of learning goals in three ways, namely through learning material through the internal processes of intellectual, emotional, and personal development of the student. Motivation helps to increase the student's personal activity (Vygotskiy, 1991).

Differentiation of the learning process is an important pedagogical condition that influences the activation of students' cognitive activity. It is the dependence of cognitive activity on the individual psycho-physiological characteristics of students that necessitates the organization of assistance to each student, taking into account different groups of success and planning for them tasks of varying complexity, thinking of different methods and methods for their submission and verification of performance (Slastenin et al., 2002; Giovazolias et al., 2019).

Creating success situations in educational and cognitive activity is an important pedagogical condition that significantly influences the activation of cognitive activity of students. From a pedagogical point of view, the success situation is such a purposeful, organized combination of conditions that are the result of a thoughtful and prepared strategy and tactics of the teacher, the family (Volchenko, 2013; López, \& Urraco, 2017). This issue has its origins in the pedagogical activity of A. Makarenko (1972), who developed the idea of tomorrow's joy, and V. Sukhomlinsky (1988), who developed this technique in the School of Joy he created. The results of these teachers' activities have formed the basis for the use of pedagogical technology in the modern school, which is aimed precisely at how to cause joy in children, to ensure learning success.

In the framework of the environmental approach to school education the success situations can also be viewed as a psychodidactic personality-oriented component of the educational environment useful for decreasing the level of students' anxiety. Therefore, in contemporary schools they are beneficial not only for academic success, but for mental and physical health of the children (Ivanova \& Sorokina, 2020).

Another effective pedagogical condition for activating students' cognitive activity is the organization of problem education. Problem-based learning refers to the deliberate purposeful activity of teachers and students in formulating learning problems, formulating them, hypothesizing them, substantiating them, and testing them in practice (Voloshchuk, 2003). The organization of active activity of students in the acquisition of new knowledge is based on the nomination by the teacher of individual problems, the formulation of problematic questions that interest the students and cause active mental activity. In addition, the teacher organizes students' activities in such a way that they want to do the job not just by the model, but try to make some personal changes.

At the present stage of the development of computer technologies, the use of a methodological computer-oriented system of education in the educational process is an important pedagogical condition for the activation of cognitive activity. The realities of today show that modern software and hardware make it possible to use computer technology at all stages of a work-study lesson (Chumak \& Klymenko, 2000).

The use of computers to support the learning process is practiced in the following cases: to illustrate and visualize educational information; demonstration of various processes and phenomena; deepening knowledge about the subject world, etc. (Kameneva, 2018). Using computer, multimedia tools in work-based training, you can demonstrate and analyze the techniques of performing technological operations, their sequence, observing the process of object change, drawing, and more (Petrov \& Berezin, 2016).

The main purpose of labor education is the formation of technologically competent person, prepared for life and active labor activity in the conditions of modern high-tech, information society for realization of students' creative potential and their socialization in society (Kobernyk \& Sydorenko, 2010). With regard to the realities of today, the issue of training students in the basics of everyday culture, getting acquainted with the technology of everyday activities, and developing the skills of social and everyday orientation is of great importance. The urgency of the above question is confirmed by the introduction to the curriculum Labor training in 5-9 grades, which students of 5-6 grade schools of Ukraine section Technology of domestic activity and self-service. This section provides students with the implementation of certain short-term projects for the acquisition of useful household skills in: setting a holiday table; use of household appliances; home care; ensuring the health and beauty of the hair. 
The quality of the organization of the educational process is directly dependent on the professional training of teachers, their knowledge of factual material and knowledge of teaching students the basics of everyday activities and self-care, awareness and realization of conditions that contribute to improving the cognitive activity of students in the classroom (Crawford et al., 2018; Sulasminten, 2016).

\section{METHOD}

\section{Participants}

The study involved a group of 34 teachers of labor education, formed in June 2019 by random cluster sampling (Denscombe, 2010) of students of advanced training courses of the Poltava Regional Institute of Postgraduate Pedagogical Education named after M. Ostrogradsky.

Participants of the ascertaining stage of the research in the 2019-2020 academic year were all 189 students of 5-6 grades aged 11-13 years of schools-gymnasiums № 6 and № 14 in Poltava in the central part of Ukraine. Of these, 93 students studied in the 5 th grade, and 96 - in the 6 th grade.

For the formative experiment in the 2019-2020 school year, students in grades 5-6 of the same schools-gymnasiums were determined by the method of typological selection by the level of success in labor education and age (Kyveryalg, 1980). The sample did not include all students in grades 5-6, but only 150 of them (76 students in the experimental group and 74 students in the control group), which in pairs corresponded to the typological features of selection. The advantage of typological selection was the guaranteed homogeneity of the initial level of training of students of control and experimental groups at the beginning of the formative experiment.

\section{Instruments}

To achieve the goal of the research, a set of modern general scientific research methods was used: theoretical - study and generalization of theoretical sources; analysis of curriculum documentation; synthesis, comparison of forms and methods of activation of students' cognitive activity; empirical: diagnostic (questionnaires with 7 questions to teachers to identify features of the application of pedagogical conditions to enhance cognitive activity of students in the classroom; questionnaire with 10 questions for students to determine their attitude to learning the basics of household activities and selfcare at work; expert assessment); observational ones (observation of the educational process at school, analysis of lessons of labor training in the topics of Technology of domestic activity and self-service in 5-6 grades, systematization and generalization of pedagogical experience); method of pedagogical experiment.

\section{Procedure}

The study aimed to determine the need and adequacy of the pedagogical conditions identified in previous scientific investigations to increase the cognitive activity of students. The correlation component of the study involved identifying the relationship between the proposed pedagogical conditions and means of effective influence on the cognitive activity of students and the principles of improving the effectiveness of labor training.

Determining the average indicators of the coefficient of knowledge acquisition made it possible to identify the level of availability of educational material on household activities and self-care for students in grades 5-6. The method of pedagogical experiment revealed the dynamics of levels of formation in students of experimental (applied author's pedagogical conditions and means of activating cognitive activity) and control (learning was carried out according to traditional methods) grades of cognitive activity during learning activities and self-care.

The experimental study was carried out with official permission from the administrations of high schools. Permits were obtained from labor training teachers who participated in surveys and experimental work. Before conducting the surveys, the introduction of experimental factors, teachers and students were informed about the ethical aspects of the content and purpose of the study. The authors of the article personally conducted interviews with study participants on the procedure and correctness of filling out questionnaires.

\section{Data Analysis}

Initially, a theoretical analysis of the conceptual construct activation of cognitive activity was conducted and the pedagogical conditions and means of activating the cognitive activity of students in grades 5-6 during the study of technology of household activities and self-service were analyzed. Questions of the peculiarities of the application of labor conditions by teachers of labor training to intensify the cognitive 
activity of students and the attitude of schoolchildren to household activities and self-care were clarified by the method of questionnaires.

The analysis of the model of activation of cognitive activity of pupils in the course of studying of technology of household activity and self-service offered by authors reveals a technique of management of cognitive activity of pupils.

The analysis of tests after studying the topic Technology of household activities and self-service by students of 5-6 grades on the average indicators of the coefficient of knowledge acquisition helped to identify the availability of theoretical educational material on the topic. Analysis of the results of ranking teachers of labor training the importance of pedagogical conditions of cognitive activity of students in the teaching of household activities and self-care, allowed the authors to avoid coincidence in their definition.

Analysis of the levels of formation of cognitive activity of students of experimental and control groups allowed to identify the effectiveness of the proposed method of activating the cognitive activity of students in the study of technologies of household activities and self-service.

\section{RESULTS}

In the course of the ascertaining stage of the study we were interested in the question of the use of pedagogical conditions by teachers of labor training to activate the cognitive activity of primary school students in the lessons of labor training. In June 2019, during refresher courses at the Poltava Regional Institute of Postgraduate Pedagogical Education, we interviewed 34 teachers of labor education of secondary schools in Poltava region. As stated by the ascertainment experiment, teachers of vocational training know the basic directions of work, which can be used to activate cognitive activity of primary school students, but they do not fully use the means and pedagogical conditions of activation of cognitive activity of students in the lessons of vocational training.

The analysis of the results of the questionnaire showed that $54.2 \%$ of the respondents paid attention to the issues of purposeful active motivation of students' educational and labor activity; used a differential approach in teaching to activate cognitive activity of students $45.8 \%$; created situations of success in the educational process to activate cognitive activity of students $-33.3 \%$ of teachers; $41.6 \%$ of teachers used this method of activating the educational process as a problem; $20.8 \%$ of teachers used computers in their work-study process to increase cognitive performance of students.

Among the difficulties of theoretical content encountered by teachers in the process of activation of cognitive activity of primary school students were the following: insufficient awareness of the theoretical bases of the process of activation of cognitive activity of students; insufficient number of methodological recommendations for activating the cognitive activity of elementary school students in specific sections and topics of the subject Labor education.

Among the difficulties of practical content encountered by teachers in the process of activating the cognitive activity of primary school students were the following: insufficient number of methodical developments on specific topics (task cards to implement a differentiated approach; task cards to provide a problematic approach to learning); complexity of selection of educational material to ensure proper motivation of students' learning activities.

At the beginning of the 2019-2020 academic year, a declaratory stage of the study took place in schools and gymnasiums № 6 and № 14 in Poltava. The authors of the article found out the attitude of students in grades 5-6 to household activities, self-care and learning their basics in the lessons of labor training. The obtained results of the survey of students gave reason to conclude that some students lack internal motivation for learning activities and the need to introduce a systematic approach to activate cognitive activity of students in 5-6 grades in the process of developing their domestic culture.

The results of the questionnaires indicate that in order to achieve the effectiveness of the process of activation of cognitive activity of students of 5-6 grades while studying their technology of domestic activity and self-care, it is important to develop a method of implementation of pedagogical conditions for the activation of cognitive activity of students of 5-6 grades in the process of mastering .

Solving the problem of substantiation of the method of activation of cognitive activity of students of 5-6 grades in the process of learning the technology of domestic activity and self-service required preliminary determination of the components of the process of managing the cognitive activity of students. Therefore, the development of a model of activation of students' cognitive activity, which is a semantic representation and a materially implemented system that adequately reflects the subject of the research and contains information about its object, occupied a special place in the search and experimental work. Creating a model of activation of cognitive activity of students of 5-6 grades in the process of learning the technology of everyday activities, we sought to ensure that this model has a structural, easy to use, orderly placement of its elements.

The model presented in Figure 1 is an attempt, based on an analysis of current views on the 
system, a systematic approach, to reveal the essence of a method of managing students' cognitive activity on the basis of personality-oriented and systematic approaches using modeling. This model reflects the connection and interaction of all links and functions of each link in the system. The model includes the following components: the process of managing students' cognitive activity; means of activating cognitive activity of students; pedagogical conditions for activation of students' cognitive activity; diagnostics of level of cognitive activity.

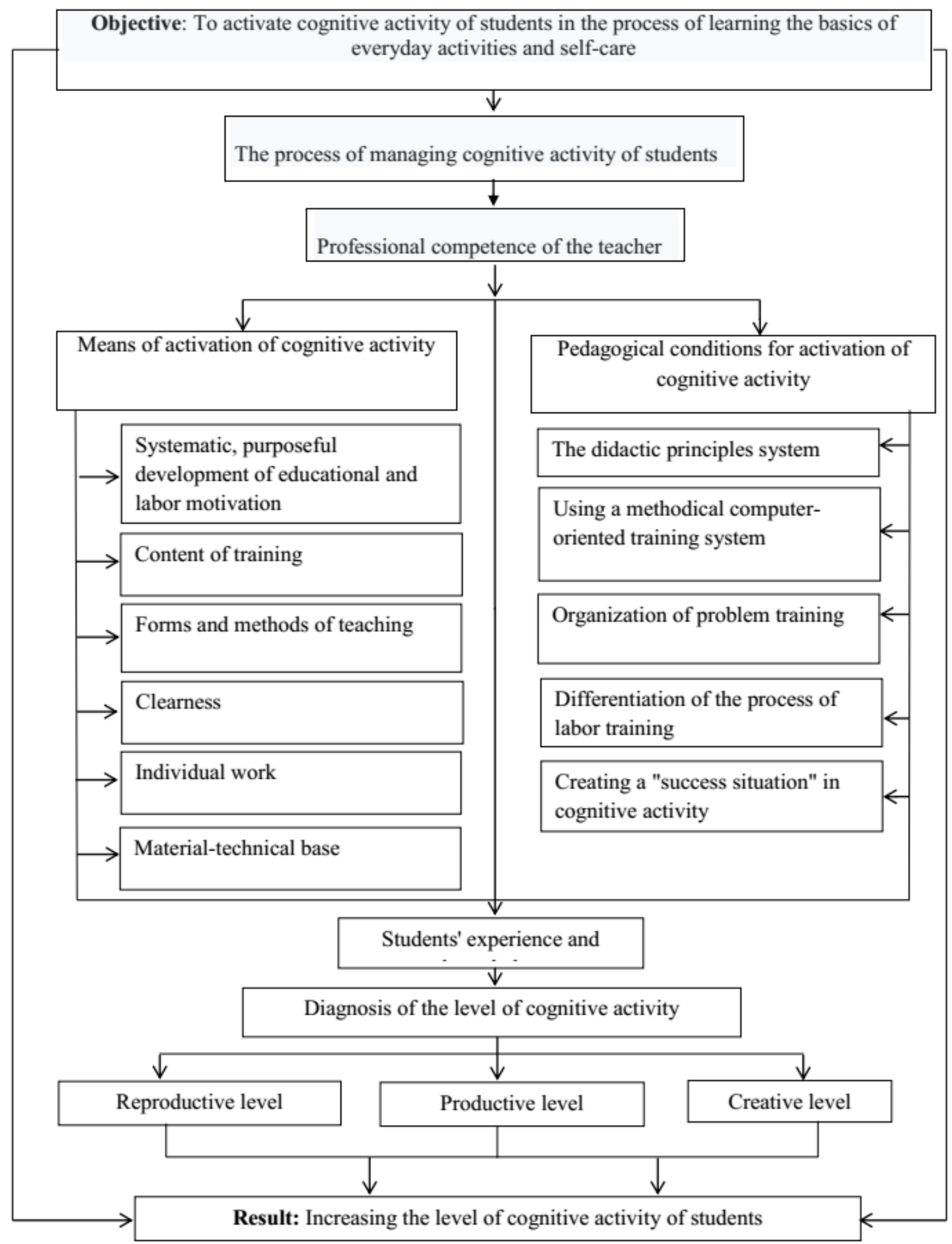

FIGURE 1. Model of activation of cognitive activity of 5-6 grade students in the process of studying technology of domestic activity and self-service 
The cognitive process management component includes such structural elements as the teacher's professional competence and the students' experience and knowledge. Elements of the Cognitive activation means component are: a system of didactic principles; the content of training; methods and forms of training organization; clearness; individual work; material-technical base. The basis of the component Pedagogical conditions for activation of cognitive activity of students are: systematic, purposeful development of motivation of students' educational and work activity; creating a success situation in cognitive activity; differentiation of the learning process; organization of problem training; using your computer in work-training lessons.

The cognitive activity diagnosis component substantiates students' levels of cognitive activity (reproductive, productive, and creative levels). In order to practically solve the tasks of the research, namely to determine the effectiveness of the proposed method of activating cognitive activity of students, there was a need to determine criteria that would allow to identify the level of cognitive activity of students at the stage of ascertaining diagnostics, to trace its dynamics during the formative experiment.

The nature of the student's activity corresponding to a particular level is shown in Table1.

Table 1. Formation levels of cognitive activity

$\begin{aligned} & \text { Level of cognitive } \\ & \text { activity }\end{aligned}$
$\begin{aligned} & \text { Characteristics of the level of } \\ & \text { cognitive activity }\end{aligned}$

\begin{tabular}{ll}
\hline Poor (low) & Involves the direct memorization and \\
& reproduction of knowledge and skills \\
& required by the curriculum.
\end{tabular}

\section{Productive (medium)}

Creative (high)
Assumes finding the essential features and relationships of objects and phenomena, applying theoretical knowledge to perform tasks on samples and algorithms, having the ability to establish cause and effect relationships.

Assumes students have the ability to apply knowledge in a new situation, find original approaches to solving problematic situations, tasks and tasks of a creative nature.
Performing the above activities is based on the performance of reproductive tasks to distinguish and memorize educational material.

Performing the above actions is based on the understanding and the simplest skills.

Performing the above actions is based on transferring the acquired knowledge and skills to new situations.

Here are the criteria by which the levels of cognitive activity of students were determined. The first criterion is the student's readiness for cognitive activity. Willingness, as a complex psychological formation, includes the following components: motivational, orientation, operational, emotionalvolitional, evaluative.

The evaluation was performed on a 10-point scale. The highest level of formation of a certain indicator was estimated at 10 points, the lowest - 1 point.

The second criterion was cognitive independence. For the reproductive level of cognitive activity, the characteristic of the student's independence will be: complete guidance and partial assistance of the teacher in certain independent steps of the student. The characteristic of the student's independence for the productive level of cognitive activity is as follows: the student, by the purpose set by the teacher, independently draws up a plan of action for the task, analyzes the actions of his and other students.

For the creative level of cognitive activity, the characteristic of the student's independence is determined by the following actions: the student acts independently, draws up a plan of action and plans of action of other students.

The third criterion is activity in cognitive activity. Its integrated indicator is the acquired knowledge and skills.

The resultant component of the model of activation of cognitive activity of students of 5-6 grades in the process of studying technology of domestic activity and self-service is the increase of the level of cognitive activity of students.

The authors of the article formative experiment was aimed at activating the cognitive activity of students by organizing the purposeful formation of cognitive activity. To participate in the experiment in 
the 2019-2020 school year, 150 students of 5-6 grades were selected from schools-gymnasiums № 6 and № 14 of Poltava. Control group A (73 students) and experimental group B (77 students) were formed.

In order to ensure the readiness of the teachers of the labor training to activate the cognitive activity of the students, at the stage of the forming experiment, they were provided with information on the activation of the cognitive activity of the students in the process of studying the technology of everyday activities and self-service. In order to provide methodological assistance to the teachers of labor training involved in the experiment, we have developed methodological recommendations for the activation of cognitive activity of students in 5-6 grades in the process of developing their culture and self-care.

In the process of developing a method of activating cognitive activity of students, we used different ways of activating cognitive activity, the main among them - the variety of forms, methods, teaching aids, the choice of such combinations that stimulate the activity and independence of students (Ihnatenko, 1997; Rieser et al., 2019; Skomorovs'kyy, 1996; Sushentsev, 2002; Zammitti et al., 2020; Giovazolias et al., 2019).

Increasing cognitive activity was based on the use of a computer to solve educational tasks. It is worth noting a special role in the activation of educational and cognitive activities of students of multimedia presentations, which provide the opportunity to form a learning motive, the main of which is interest in the subject. Thus, the teacher not only explains the teaching material, but also organizes the cognitive activities of the students. First of all it is important to arouse interest in the topic, to show the students the need to study it and the logic of studying each of its issues. We have developed a complex of multimedia presentations, for each of the topics of the section Technology of household activities and selfservice (5-6 grades), the content of which has a significant motivational impact on students and leads them to realize the importance of studying program material.

Significant developmental effect on lessons from technology of domestic activity will create situations in which students themselves should: defend their opinion; to participate in discussions and discussions; ask questions of your classmates and teacher; evaluate the responses and written works of comrades; to train the lagging behind; to explain to the students incomprehensible moments; independently select feasible tasks; find several options for a possible solution to a cognitive problem (problem); create situations of self-examination, analysis of personal cognitive and practical actions; solve cognitive problems by comprehensively applying their known solutions.

This approach to the construction of the educational process in mastering students section Technology of domestic activities and self-service makes it expedient to use progressive methods, namely: problem learning, discussion, educational, business and role-playing games, individual approach and differentiation of learning (use of multi-level cards), creative tasks. Computer support for student cognitive activity increases the ability to find specific information, allows for quick and reasoned retrieval of certain data from the basics of everyday activities, and increases students' interest in learning self-care.

It is advisable to create success situations in the process of teaching students the basics of everyday activities and self-service as an important condition for the development of the child's personality. A number of topics, the content of which is close to life and of particular interest to students, allow the teacher to significantly influence the stimulation of cognitive activity of students (López \& Urraco, 2017).

Increasing student activity is facilitated by the use of group forms of organization of design and technological activities in the lessons of everyday life technology, in the course of which work planning, discussion and choice of ways to solve specific problems, mutual assistance and cooperation, mutual control and mutual evaluation are carried out.

The process of experimental verification of the developed methodology involved the authors of the article determining the availability of the content of educational material and was based on diagnosing the theoretical knowledge of students. After students of 5-6 grades of gymnasiums № 6 and № 14 of Poltava mastered the study material of the topics of the section Technology of household activities and selfservice in order to determine their mastery of theoretical knowledge in May 2020, the authors conducted tests. In the development of control works, the state requirements for the level of general education of the student, which are enrolled in the curriculum were taken into account (Navchal'ni prohramy, 2017).

In the course of the analysis of the control works, students' knowledge was evaluated by each component of the knowledge that was presented for assimilation (terms, concepts, properties, means of work, methods of work, events, etc.). A conditional rating was set: 1 was given for the correct answer, and 0 was given for the wrong or wrong answer. The absorption coefficient was calculated by the formula (Entsyklopediya osvity, 2008): 


$$
K_{\text {assim }}=\frac{100 B_{c}}{n}
$$

$\mathrm{B}_{\mathrm{c}}$ - the sum of conditional points;

$n$ - number of components.

Given that the results of the control work may be influenced by random circumstances (students 'psychological state, fatigue, ability to write off, etc.), adequate conclusions were drawn about the students' level of knowledge by analyzing the averages as they are more stable than individual values. Therefore, in this case, the average rate of assimilation of theoretical information by a group of students, being more stable value, allowed to make sound conclusions about the level of assimilation of educational material under the section Household technology and self-service as a whole.

Thus, having determined the coefficient of assimilation of educational material by each student, we found on these indicators the average relative indicators of the coefficients of assimilation of knowledge in the section Technology of domestic activity and self-service. The results of determining the average indicators of the knowledge absorption coefficients from the section Technology of household activities and self-service are shown in Table 2.

Table 2. Average indicators of the absorption of knowledge from the section Technology of household activities and self-service, \%

\begin{tabular}{lll}
\hline Educational grade & Grade 5 & Grade 6 \\
\hline Control grades, group A & 63.7 & 67.8 \\
Experimental grades, group B & 74.9 & 76.5 \\
\hline
\end{tabular}

As can be seen from Table 2, the average indicator of the mastery of knowledge of students of control and experimental grades in the section Technology of household activities and self-service can be considered sufficient, since it is in the range of $60-80 \%$ (Entsyklopediya osvity, 2008). The results obtained show that the availability of the theoretical part of the educational material is within the accepted norm.

To eliminate coincidences in determining the pedagogical conditions for activating the cognitive activity of students in grades 5-6 in the lessons of labor training in the process of studying the section Technology of household activities and self-service to a group of teachers of labor education (experts) of schools in Poltava Regional Institute of Postgraduate Pedagogical Education in June 2019, the authors of the article, proposed to rank the importance of pedagogical conditions that will effectively increase the cognitive activity of students in lessons on specific topics in the above section.

The results of the questionnaire showed that the specific content of the topics of the section Technology of household activities and self-service causes the use in the process of activating cognitive activity of students in the first place those pedagogical conditions that scored more points (pedagogical conditions indicated according to the rankings from more significant to less significant): (i) systematic, purposeful development of motivation of students' educational and labor activity; (ii) the use of a methodological computer-oriented training system; (iii) organization of problem training; (iiii) differentiation of the process of labor training; (iiiii) creating a success situation in cognitive activity.

Cognitive activity is an integral criterion for the effectiveness of experimental work. The generalized results of the forming experiment are shown in Figure 2. 


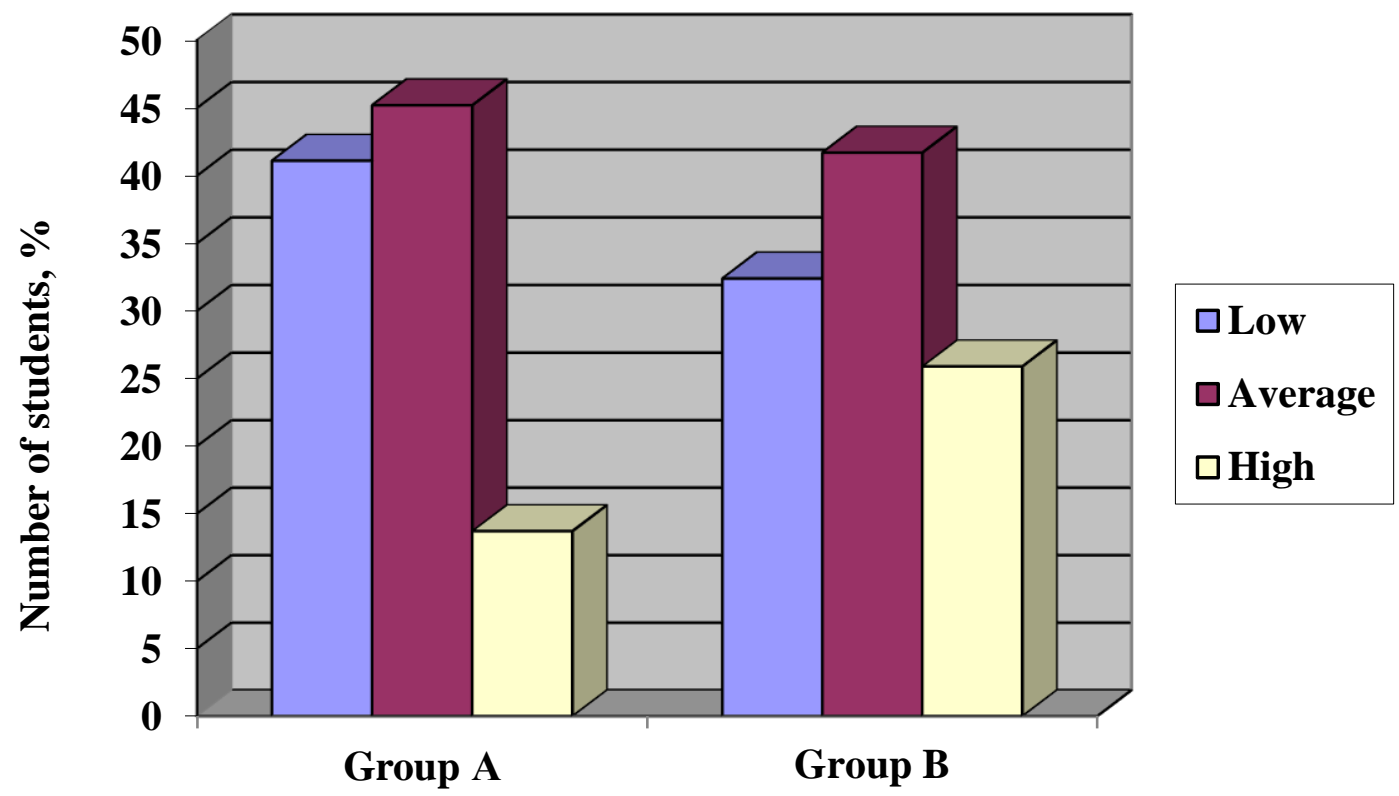

FIGURE 2. Dynamics of change of level of cognitive activity of students of 5-6 grades at lessons of labor training at studying of technology of household activity and self-service

Changes in the levels of cognitive activity formation testify to the effectiveness of the proposed method of activation of cognitive activity of students of 5-6 grades in the lessons of labor training in the process of studying their technology of domestic activity and self-care.

\section{DISCUSSION}

Based on the analysis of the results of the study of the effectiveness of the proposed method of activation of cognitive activity of students of 5-6 grades in the lessons of labor training in the process of studying technology of domestic activity and self-service, we found that it is expedient to expand the list revealed in previous studies, pedagogical conditions of increasing cognitive activity of students (system of creative cognitive tasks, inclusion in the educational process of information and communication technologies (Kameneva \& Bondarenko, 2018)), intrinsic motivation (Rieser et al., 2016); Zammitti et al., 2020; Becerra-Romero et al., 2020), situations of success (Volchenko, 2013) such pedagogical condition as differentiation of the process of labor training in order to take into account individual psychophysiological features of students.

Expert study of the importance of pedagogical conditions of effective influence on the cognitive activity of students showed their high correlation with the principles of improving the effectiveness of learning by means of a positive atmosphere, microclimate and management of cognitive activity of students, grounded in the studies of W. Plöger et al. (2019), S. Rieser et al. (2016), M. Mahfud et al. (2020), R. Haruna et al. (2019).

The obtained results give grounds to state the availability of educational material of the school program within the accepted norm. At the same time, as can be seen from Table 2, due to the applied pedagogical conditions and means of activating cognitive activity of students, the average index of mastering the knowledge of students of the experimental grades in the section Household technology and self-service exceeded the indicators of students of the control grades: by $11,2 \%$ in 5 grades and by $8,7 \%$ in 6 grades.

Summarizing the data of the conducted research (Figure 2) allowed us to determine the percentage ratio of the levels of cognitive activity of students in the study of household activities and self-care: high (creative) level - 25.9\%; average (productive) level - 41.7\%; low (reproductive) level - 32.4\%; in control groups, respectively, $-13.7 \% ; 45.2 \% ; 41.1 \%$.

Due to the experimental work in the experimental group, the high level of cognitive activity of students in the study of household activities and self-care increased by $12.2 \%$ compared to the control group, the average level decreased by $3.5 \%$, the low level decreased by $8.7 \%$.

Comparison of the results of the experimental groups with the control data revealed by the students, who studied according to the traditional method, which did not take into account the 
pedagogical conditions and means of activating the cognitive activity of students of 5-6 grades in the process of studying technology of household activities and self-service, showed a positive dynamic that shows the positive effectiveness of the proposed innovations.

Thus, the result of the formative experiment was a significant increase in the level of formation of cognitive activity of students in the study of domestic activities and self-service, which is a confirmation of the effectiveness of the system of our means and pedagogical conditions of educational and educational work that provide activation of cognitive activity of students in 5-6 grades.

\section{CONCLUSION}

Determining ways of successful activation of cognitive activity of students in the modern secondary school has shown that it is advisable to use various means of activating their cognitive activity in order to increase the activity of students in the lessons of work training. It is a system of didactic principles, content of teaching, stimulation of cognitive activity, non-traditional forms of organization of training, active methods of teaching, cross-curricular relations, independent work of students, material and technical base of school workshops and more. Theoretical analysis of the ways of activating the cognitive activity of students in the lessons of labor training gave grounds to highlight the effective pedagogical conditions for increasing the cognitive activity of students in the educational process. They include the following: systematic, purposeful development of motivation of educational and labor activity, creation of a success situation in cognitive activity, differentiation of the process of labor education, organization of problematic learning, use of methodical computer-oriented system of training.

The model of activation of cognitive activity of students of 5-6 grades in the process of studying technology of domestic activity and self-service is developed. The main substructural components of this model are: the process of managing students' cognitive activity; means of activating cognitive activity of students; pedagogical conditions for activation of students' cognitive activity; diagnostics of level of cognitive activity. The method of activation of cognitive activity of students of 5-6 grades in the process of studying technology of everyday activity is developed. The result of the work was a clear system of forms and methods of educational work with students aimed at enhancing the cognitive activity of students.

The effectiveness of the method of activation of cognitive activity of students of 5-6th grade in the process of studying the technology of everyday activity was experimentally tested. The research work was based on determining the availability of the content of training, the level of formation of cognitive activity of students. Generalization of the results of experimental work showed significant changes in the level of cognitive activity of students, in the formation of cognitive independence and improving the quality of knowledge, skills and skills of students, which confirmed the effectiveness of the proposed method of activating cognitive activity and students in the process of technology and students selfservice.

\section{REFERENCES}

Becerra-Romero, J. P., Bahamón, M. J., Rubio-Castro, R., Barraza-López, R. \& Cudris-Torres, L. (2020). Promoción de habilidades para la vida en los estudiantes de una institución de formación para el trabajo y el desarrollo humano de la ciudad de Barranquilla. Colombia [Promotion of life skills in students of a training institution for work and human development of the city Barranquilla, Columbia]. Archivos Venezolanos de Farmacologia y Terapeutica, 39 (3), 349 - 354.

Berbets, V. V., Dubova, N. V., \& Kobernyk, O. M. (2003). Metodyka orhanizatsiyi proektno-tekhnolohichnoyi diyal'nosti uchniv na urokakh obsluhovuyuchykh vydiv pratsi: navchal'no metodychnyy posibnyk [Methods of organizing design and technological activities of students in the lessons of service types of work: a textbook]. Kyiv: Naukovyy Svit.

Bondarchuk, O. I. (2001). Pedahohichnyy slovnyk [Pedagogical dictionary]. Kyiv: Pedahohichna Dumka.

Chumak, A., \& Klymenko, V. (2000). Vykorystannya komp"yuteriv u protsesi trudovoho navchannya uchniv u shkoli [The use of computers in the process of labor training of students in school]. Ridna Shkola, 10, 36 - 38.

Crawford, S., Hadley, D. M., \& Shepherd, G. (Eds.) (2018). The Oxford Handbook of the Archaeology of Childhood. University of Oxford, United Kingdom. https://www.doi.org/: 10.1093/oxfordhb/9780199670697.001.0001

Davydov, V. V. (1996). Teoriya razvivayushchego obucheniya [The theory of developmental learning]. Moscow: Intor.

Denscombe, M. (2010). The good research guide: For small-scale social research projects, (4th ed.). Buckingham: Open University Press.

El'konin, B. D. (2004). K probleme periodizatsii psikhicheskogo razvitiya $\mathrm{v}$ detskom vozraste [On the problem of periodization of mental development in childhood]. Voprosy psikhicheskogo zdorov'ya 
detey i podrostkov, 1, 68 - 77.

Entsyklopediya osvity [Encyclopedia of Education]. (2008). V. H. Kremen' (Ed.). Kyiv: Yurinkom Inter.

Gal'perin, P. Ya. (1992). Moyo mirovedeniye: kurs lektsiy [My world study: a course of lectures]. Moscow: ROU.

Giovazolias, T., Syngelaki, E. M., \& Papastylianou, A. (2019). Effectiveness of a teachers' training program on their core self-evaluations, relationship with students and work engagement. Journal of Classroom Interaction, 54 (2), 4 - 23.

Haruna, R., Kamin Y.B., \& Buntat, Y.B. (2019). Understanding work-based learning in technical and vocational education and training in Nigeria. International Journal of Recent Technology and Engineering, 8(1), 1726 - 1733.

Hornsby-Gutting, A. (2019). "Woman's Work": Race, foreign missions, and respectability in the national training School for women and girls. Journal of Women's History, 31(1), 37 - 61. https://www.doi.org/10.1353/jowh.2019.0002

Ihnatenko, M. Ya. (1997). Metodolohichni ta metodychni osnovy aktyvizatsiyi navchal'no-piznaval'noyi diyal'nosti uchniv starshykh klasiv pry vyvchenni matematyky [Methodological and methodical basis for activization of educational and cognitive activity of the senior grades students at studying mathematics]: 13.00.02. [Doctoral dissertation, Drahomanov State Pedagogical University]. Kyiv.

Ivanova, N., \& Sorokina, T. (2019). Educational environment approach to preventing the growth of school students anxiety in the transition from primary to secondary school. Elementary Education Online, 19(1), 333 - 342. https://www.doi.org/10.17051/ilkonline.2020.661841

Kaloshyn, V. F. (2011). Pedahohika uspikhu [Pedagogy of success]. Pedahohichna Maysternya, 10, 9 - 15.

Kameneva, G. A., \& Bondarenko, T. A. (2018). Educational factors in enhancing students' learning and cognitive activities within the framework of educational informatization. Novosibirsk State Pedagogical University Bulletin, 8(4), 172 - 186. https://www.doi.org/10.15293/22263365.1804 .11

Karpenko, L. A. (1990). Psikhologiya: slovar' [Psychology: a dictionary]. Moscow: Politizdat.

Kobernyk, O. M. (2011). Suchasni problemy vprovadzhennya proektnoyi tekhnolohiyi na urokakh trudovoho navchannya [Modern problems of project technology implementation in labor training lessons]. Trudova Pidhotovka v Zakladakh Osvity, 3, 3 - 6.

Kobernyk, O. M., \& Sydorenko, V. K. (2010). Kontseptsiya tekhnolohichnoyi osvity uchniv zahal'noosvitnikh navchal'nykh zakladiv Ukrayiny (Proekt) [The concept of technological education of students in Ukrainian secondary schools (A project)]. Trudova Pidhotovka $v$ Zakladakh Osvity, 6, 3 - 11.

Kostyuk, G. S., \& Prokoliyenko, L. N. (1988). Izbrannyye psikhologicheskiye trudy [Selected psychological works]. Moscow: Pedagogika.

Kyveryalg, A. A. (1980). Metody issledovaniya v professional'noy pedagogike [Research methods in professional pedagogy]. Tallinn: Valgus.

Leont'yev, A. N. (1975). Deyatel'nost'. Soznaniye. Lichnost' [Activity. Consciousness. Personality]. Moscow: Politizdat.

López, V. H., \& Urraco, E. G. (2017). Do you study or work? the decision making in the training pathways of young people. Profesorado-Revista de Curriculum y Formacion de Profesorado, 21 (4), 139 - 157.

Lozova, V. I., \& Trotsko, H. V. (2002). Teoretychni osnovy vykhovannya i navchannya: navch. posib.dlya vuziv [Theoretical foundations of education and training: a textbook for universities]. Kharkiv: Osvita. Vykhovannya. Sport.

Mahfud, M., Hermawati, W., \& Pujiastuti, E. (2020). The effect of training and communication on work motivation and its implications in performance of public high school teachers in Cirebon city. Test Engineering and Management, 82 (1-2), 1821 - 1828.

Makarenko, A. S., \& Kumarin, V. V. (1972). Kollektiv i vospitaniye lichnosti [Team and personality education]. Moscow: Pedagogika.

Navchal'ni prohramy dlya zahal'noosvitnikh navchal'nykh zakladiv: trudove navchannya, 5-9 klasy [Curricula for secondary schools: labor training, grades 5-9]. (2017). Labor training. Grades 5-9: a practical guide for teachers. Kharkiv: Ranok.

Petrov, N. U., \& Berezin, N. U. (2016). Use of modular training systems in secondary school students' project work. In 13th International Scientific-Technical Conference on Actual Problems of Electronic Instrument Engineering, APEIE 2016 (Vol. 1, pp. 333-335), Novosibirsk. https://www.doi.org/10.1109/APEIE.2016.7802289 
Plöger, W., Krepf, M., Scholl, D., \& Seifert, A. (2019). Looking in the heads of experienced teachers - Do they use the wide range of principles of effective teaching when analysing lessons? Australian Journal of Teacher Education, 44(1), 21 - 35. https://www.doi.org/10.14221/ajte.2018v44n1.2

Rieser, S., Naumann A., Decristan J., Fauth B., Klieme E., \& Büttner G. (2016). The connection between teaching and learning: Linking teaching quality and metacognitive strategy use in primary school. British Journal of Educational Psychology, 86(4), $526 \quad$ - 545. https://www.doi.org/10.1111/bjep.12121

Savchenko, O. Ya. (1997). Dydaktyka pochatkovoyi shkoly [Didactics of primary school]. Kyiv: Abrys.

Shamova, T. I. (1982). Aktivizatsiya ucheniya shkol'nikov [Revitalizing the teaching of schoolchildren]. Moscow: Pedagogika.

Shamova, T. I., Tret'yakov, P. I., \& Kapustin, N. P. (2002). Upravleniye obrazovatel'nymi sistemami: ucheb. posobiye dlya stud. vyssh. ped. ucheb. zavedeniy [Management of educational systems: a textbook for students of higher pedagogical educational institutions]. Moscow: Akademiya.

Skomorovs'kyy, B. H. (1996). Dydaktychni zasady rozvytku poshukovoyi piznaval'noyi aktyvnosti uchniv seredn'oyi shkoly [Didactic basis of developing the search cognitive activity of high school students]: 13.00.01. [Abstract of doctoral dissertation, Ukrainian Institute for Advanced Training of Educational Managers]. Ivano-Frankivsk.

Slastenin, V. A., Isayev, I. F., \& Shiyanov, Ye. N. (2002). Pedagogika: uchebnoye posobiye dlya studentov vysshikh pedagogicheskikh uchebnykh zavedeniy [Pedagogy: a textbook for students of higher pedagogical educational institutions]. Moscow: Akademiya.

Sukhomlinskiy, V. A. (1988). O vospitanii [On education]. Moscow: Politizdat.

Sulasminten, E. (2016). A study of relationship between cultural value orientation, training experience, compensation with work motivation and teacher performance. Man in India, 96 (5), 1475 - 1484.

Sushentsev, O. Ye. (2002). Zasoby navchannya ta yikh vplyv na aktyvizatsiyu piznaval'noyi diyal'nosti uchniv na urokakh tekhnichnoyi pratsi [Means of learning and their influence on the stimulation of cognitive activity of students in lessons of technical labor]. In Trudova ta profesiyna pidhotovka molodi: problemy ta shlyakhy yikh rozv'yazannya [Labor and professional training of youth: problems and solutions]: a collection of scientific works (Issue 4, pp. 106 - 109), Kryvyi Rih.

Sushentseva, L., \& Sushentsev, O. (2000). Pidvyshchennya aktyvizatsiyi piznaval'noyi diyal'nosti uchniv na urokakh trudovoho navchannya [Increasing the stimulation of cognitive activity of students in the lessons of labor training]. Ridna Shkola, 9, 70 - 72.

Tkhorzhevs'kyy, D. O. (2000). Metodyka trudovoho ta profesiynoho navchannya [Methods of labor and professional training]. Kyiv: RNNTS DINIT.

Volchenko, L. (2013). Model' profesiynoho uspikhu [Model of professional success]. Upravlinnya Osvitoyu, $7,28-35$.

Voloshchuk, I. S. (2003). Kontseptual'ni zasady rozvytku tvorchykh zdibnostey shkolyariv [Conceptual bases of development of creative abilities of school students]. Trudova Pidhotovka v Zakladakh Osvity, 3, 4 - 9.

Vygotskiy, L. S. (1991). Pedagogicheskaya psikhologiya [Pedagogical psychology]. Moscow: Pedagogika.

Wischgoll, A., Pauli, C., \& Reusser, K. (2019). High levels of cognitive and motivational contingency with increasing task complexity results in higher performance. Instructional Science, 47 (3), 319 - 352. https://www.doi.org/10.1007/s11251-019-09485-2

Yashchuk, S. M. (2002). Orhanizatsiyno-metodychni peredumovy vykonannya uchnyamy tvorchykh proektiv. In V. H. Kuz' (ed.). Zbirnyk nauk. prats': Spetsial'nyy vypusk [Collection of scientific works: Special issue] (pp. 127 - 132). Kyiv: Naukovyy svit. 